\title{
Competition between offline and online stores: which will Indonesian consumers choose to shop for fashion products?
}

\author{
$1^{\text {st }}$ Dede Suleman, $2^{\text {nd }}$ Ida Zuniarti, $3^{\text {rd }}$ Ratnawaty Marginingsih, $4^{\text {th }}$ Sabil, $5^{\text {th }}$ Ety Nurhayaty, \\ $6^{\text {th }}$ Susan Rachmawati, $7^{\text {th }}$ Eigis Yani Pramularso, $8^{\text {th }}$ Imelda Sari \\ \{dede.dln@bsi.ac.id ${ }^{1}$, Ida.idz@bsi.ac.id ${ }^{2}$,ratnawaty.rmg@bsi.ac.id ${ }^{3}$, sabil.sbl@bsi.ac.id ${ }^{4}$, \\ ety.eyy@bsi.ac.id ${ }^{5}$ susan.srw@bsi.ac.id ${ }^{6}$, eigis.eyp@bsi.ac.id7.imelda.isx@bsi.ac.id $\left.{ }^{8}\right\}$
}

\author{
Management and Business Faculties Bina Sarana Informatika University
}

289 Dewi Sartika St., Cawang, Jakarta Timur, ID

\begin{abstract}
In this era, the emergence of new shopping patterns with online media, of course, will disrupt the existing market with the existence of this new market to become a market in the offline store as long as it has another new alternative that can be used as a place of shopping by consumers. Because of this in this study will describe the choice of consumers whether in buying fashion products they will choose to shop at an offline store or online store. This qualitative research by distributing questionnaires to 154 respondents to make choices in deciding to shop for their fashion products in offline or online stores. The results of the study found that shopping decisions for fashion products in Indonesia found that consumers still choose to shop in an offline store. This is based on the factors Perceived usefullnes, Perceived Eases of use, trust, Risk, about the comparison between offline and online stores. Bad shopping experience in online stores makes Indonesian consumers still believe that the offline store is better and the right place
\end{abstract}

Keywords: Perceived usefullnes, perceived Ease of use, Trust, Risk, Purchase decision

\section{Introduction}

In the development of the current era the birth of this new information technology is called the internet. The presence of the internet has changed all activities which in the end can facilitate human activities. A new era has come and it is inevitable that technological developments will surely change the business map. One well-known model of change is the trade model. Today's world development and changing very quickly when an internet technology begins to develop rapidly, increasing from the first internet to all alternative new concepts which are a discovery and breakthrough new things to continue to make things easier which ultimately aims to facilitate all activities in human life will continue to be created [1]. Offline market or retail seller who sells goods and services physically by opening a store and displaying their goods and services directly we have long known so far with existing shopping methods where consumers and traders meet to transact. Currently having to fight with a new transaction method or concept which is often called online retailing, the emergence of online 
retailing is based on the use of information technology to make transaction activities easier and faster and can be done anywhere. This condition gave rise to the term designation of a new marketing method for marketers or companies in marketing their products, namely by the name of marketing they will carry out their marketing activities between two places or one place or called brick and click [2].

Indonesia with a large population is a large market potential which has so far only been an alternative place of shopping to be another option which is currently trending in this era, namely online retail. With a large population making the opportunity itself, especially in Southeast Asia, this can occur because of the possibility of migration from increasing internet users in Indonesia which is a gateway for consumers to transact online. Data shows that the increase in internet users every year, has increased from data shows that internet users until 2012 numbered approximately 2.41 billion users worldwide. This number represents around $34.3 \%$ of the total world population. Internet users are widespread nowadays because this internet technology is used for all human activities and in all its advancements, the internet not only has a revolutionary impact on people's lives, but also its impact on business operations [3]. And other indicators that can be used as a reference that Indonesia is a large market is the growth of smart phone users and the like which is an important part of being able to transact online [4].

The era of online marketing exists and arises because of internet technology infrastructure that can connect people around the world, so people can share knowledge and information both through e-mail media, digital publications, shopping, looking for news and so on [5]. One of the things that is changing is in the business model, especially the transaction system that used to only recognize offline transactions, we present a new method called online transactions. Online transactions are transactions that do not occur face to face because consumers' needs for information can be done with gadgets and other devices to be able to find information on goods and services needed by consumers so that consumers can better understand products and services and can decide for their purchasing decisions with comparing between buying at offline retail and online retail [6]. Besides that online shopping has its own advantages and benefits [7]. Advantages of shopping online First, it allows consumers to buy products and services anytime 24 hours and wherever they are as long as they have an internet network. Second, online shopping can save consumers money, effort and time when buying products or services. For example, a comparison between producers and online then the price for certain products can be easily and efficiently if shopping online. Online details are conducting trade or business transactions using internet media and other devices [8]. Online retail in this case refers to the use of the Internet and other networks (intranets) that carry out buyers, sell, transport, or trade data, goods, or services [9]. It can be called a business innovation today that involves non-physical or electronic interactions, and maintenance of business relationships through sharing information and knowledge [10]. The question arises whether with the ease and excellence of existing online retailers will make consumers always and decide shopping at online retail and forget the old way of shopping by shopping at offline retail.

The behavior of a consumer is not easy to infer and predict, this is where an important role for marketers to study their perceptions, preferences, and behavior in shopping [11]. One form of consumer behavior is the desire to buy a product or service. Buying interest is the stage of the respondent's tendency to act before the buying decision is actually implemented into a buying decision. Buying interest is related to feelings and emotions, if someone is happy and satisfied in buying a product, it will strengthen the buying decision in [12]. Consumer behavior is the study of how individuals, groups, and organizations choose, buy, use, and 
dispose of goods, services, ideas, or experiences to meet their needs and desires [13]. This is where we will examine how consumers from the internal side of consumer attitudes will prefer shopping for fashion products in offline retail or online retail.

Attitude is an enduring organization that includes processes of motivation, emotions, perception and cognitive relating to several aspects of our environment. Then the attitude of choosing can be interpreted as a way for someone to think, feel, and act on several aspects of their environment, such as choosing retail offline or online, television programs or products [14]. Humans behave or do activities because there is a need to achieve a goal. With the need for motivation or mobilization will emerge. So that individuals will be active to achieve goals and experience satisfaction [15]. There are at least 3 levels of behavioral areas namely knowledge, attitude and action or practice. Forming consumer attitudes to shop for shopping choices consists of two variables perceived usefulness and perceived ease of use and trust [16]. And it has also been investigated that consumer attitudes in choosing can also be influenced by risk [17]. Or according to [3] consumer attitudes choose because of the benefit or enjoyment factor offered from the store and choose to shop at one of the stores of choice for consumers in shopping for fashion products. In choosing to shop between in offline retail or online retail, there are certainly some considerations made by consumers, among others, they will choose according to choices in themselves arising from how these predictors affect consumers and what is most important that is considered by each consumer.

\section{Material And Methods}

Researchers try to examine what variables are the first and last order in the priority of consumer attitudes in choosing where to shop offline or online. And also on the other hand that is a barrier or concern for consumers in deciding to shop at one of these stores. Therefore, a survey of 154 consumer respondents with age criteria ranging from 17 years and above has done a purchase of fashion products both offline and online. And in the end you will be able to see the percentage of factors that influence the attitude of consumers during the decision before choosing to shop in offline retail or online retail. By looking at consumers' decisions when shopping for fashion products, they would prefer to shop in offline retail or online retail.

\section{Results And Discussion}

Samples are selected based on specific criteria found in the population. The criteria used include: consumers shopping decisions online fashion products, respondents with ages starting 17 years and have never made a purchase of fashion products either offline or online. Table 1 summarizes the demographics of respondents from the descriptive analysis of this study as follows:

Table 1. Demographic profile responden

\begin{tabular}{llll}
\hline Measure & Items & Frequency & Persen $\%$ \\
\hline
\end{tabular}




\begin{tabular}{|c|c|c|c|}
\hline \multirow[t]{2}{*}{ Gender } & Male & 100 & 35.1 \\
\hline & Female & 54 & 64.9 \\
\hline \multirow[t]{3}{*}{ Age } & Under 21 & 67 & 43.5 \\
\hline & $22-41$ & 68 & 44.2 \\
\hline & Over 42 & 19 & 12.3 \\
\hline \multirow[t]{3}{*}{ Education Level } & High school & 87 & 56.5 \\
\hline & Diploma / Bachelor's degree & 33 & 21.4 \\
\hline & Graduate degree & 34 & 22.1 \\
\hline Place Options & Retail offline & 102 & 66.2 \\
\hline Place Options & Retail online & 52 & 33.8 \\
\hline
\end{tabular}

Based on the results of the analysis it was found that respondents, 35.1 percent were men and 64.9 percent were women, 43.5 percent were under 21 years old and 44.2 percent were aged between $22-41$ and 12.3 percent aged over 42 years; the percentage of respondents 56.5 percent had a high school education and 21.4 percent had a Diploma / Bachelor's degree and the remaining 22.1 percent had a graduate degree, while judging by the choice of fashion product shopping places the respondents found that 66.2 percent chose shopping at online retail and 33.8 percent chose shopping at retail offline.

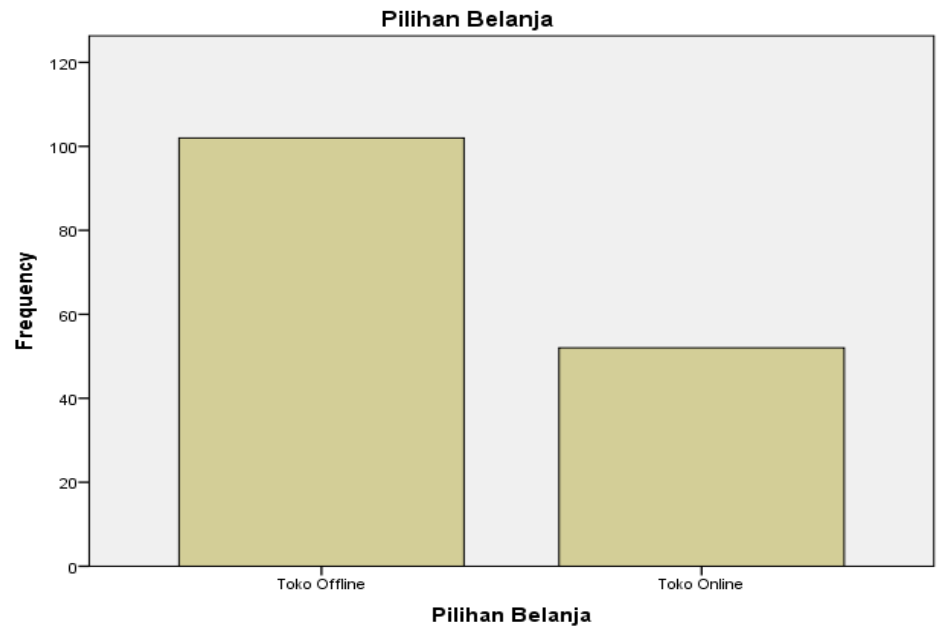

Figure 1 : Output Options Consumer shopping places

In Figure 1.1 above shows the unexpected results of researchers where it turns out that Indonesian consumers in choosing where to shop, especially fashion products, still believe more in offline retail as their place of shopping in the sense of the presence of online retail with all kinds of advantages yet can attract consumers to decide to shop for fashion products. in online retail. Because, especially in fashion products, there are things that cannot be fulfilled by online retailers regarding the needs of consumers in considering buying decisions, among others: not being able to try the product first because in purchasing fashion products, greater emotions affect buying decisions. This 
can be interpreted and translated further in the discussion of this study later what is considered why consumers still prefer to shop at offline retail.

This gender data shows that women are very selective in choosing where to shop, especially for fashion products. In terms of shopping women have many of their personal considerations. The conclusion is that female consumers play an important role in making decisions about where to shop and make up the largest percentage of the consumer population.

Age in this study shows that millennials are only partially comfortable adapting online shopping methods and others are still using to compare old shopping methods in offline retailing and occasionally trying to shop online. Because the data shows that the combination of gen $X$ generation aged over 42 years and millennial generation 22-41 this year is a lot, but the conclusion is that there are still many who choose to shop at offline retail. That should be if the current millennial generation has migrated to online retail then the end result will show that online retail is preferred in shopping for fashion products. Because a generation under 21 is called Generari Z or Linkster, of course, choose to shop at online retail because in the era of those born and raised by technology, it has become comfortable with what is offered by current changes. According to age, it is still controlled by Generation $\mathrm{Z}$ in numbers. but in this case the final decision was also obtained that offline retail is the main choice for shopping. This situation can be concluded that indeed in selling fashion products, what is the advantage of offline retail cannot be replaced. Age is not a certainty that Generation $\mathrm{Z}$ will definitely choose shopping at online retail even though the generation in daily activities always uses technology but cannot change their decision in choosing where to shop.

Next will discuss what factors are considered by consumers in deciding on choosing a shopping place. Certainly every decision of consumers has a basis for consideration in this case one of the basics is the attitude of consumers or consideration of the data from within the consumer over various alternatives and calculate profits. his loss for each place to shop, which in turn led to a decision where to shop for their fashion products. In this study we discuss personal consumer attitudes about how decisions are made. In Figure 1 illustrates the magnitude of the percentage of variables that need to be considered by marketers in terms of changing consumer decisions later in choosing where to shop can be seen as follows:

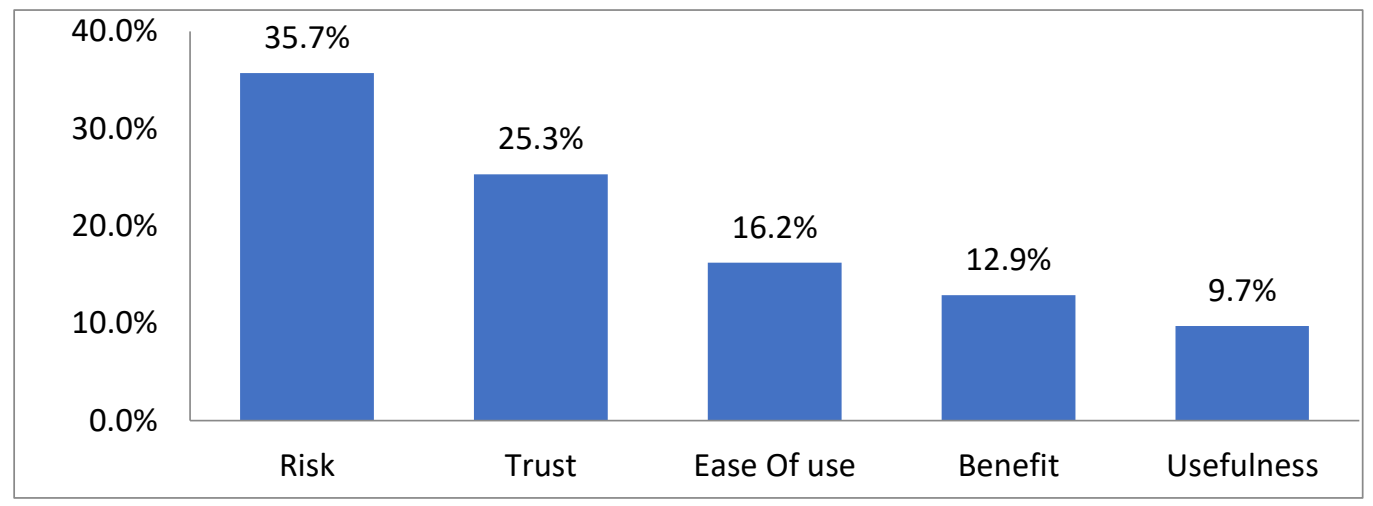

Figure 2. Percentage of consumer attitude factors 
In figure 2 can be seen several variables of consumer attitudes examined in this study, among others, perceived usefulness, perceived ease of use, trust, risk and benefit. It can be seen above that it turns out that risk factors are still the most considered factors of consumers in deciding to choose a place to shop because the risk of 35.7 percent or 55 respondents think about risk as the main thing in the transaction. This relates to the security of money and also the goods that they will get in accordance with the money paid because consumers cannot directly touch and feel the products sold through online retail.

Then the second big variable that consumers consider is trust being a priority for 39 respondents or 25.3 percent. Regarding risk, of course trust is another factor that makes the transaction happen because in this sophisticated era with information technology, the type of crime is increasing, which will make consumers suffer losses when they trust online retailers who do not intend to make transactions. So choosing offline retail as a shopping place is a wise decision in the transaction according to most respondents. But in the future also with the improvement of online retailing and the growing of new concepts such as market place will make consumers more confident in online retail. But another thing that is considered is the issue of the quality of products purchased by consumers currently can not believe in what is displayed needs to also feel and touch directly the fashion products they will buy so that offline retail choices are the right thing to meet consumer expectations in addition to being able to see, try and Touch can also directly transact with sellers so that consumers trust more.

In the third place chosen by 25 respondents or equivalent to $16.2 \%$ percent, the consumer's consideration is related to the perceived ease of use of this factor about how the convenience process that consumers get in shopping for fashion products. This convenience relates to how to transact in this case offline retailing is considered easier in the shopping process and is not too complicated the process without the need to go through several stages of being able to direct transactions and communication with sellers.

Furthermore, for the benefits prioritized by 20 respondents or equal to 12.9 percent of consumers have thoughts about what is offered by each store and compared then summarized. Although there are many advantages offered by online retail, it is still according to the respondents that it is concluded that in this study the advantages of offline retailing are more than online retailing. This can be seen from the respondents of this study, more and more decided to shop for their fashion products through offline retail

And finally 15 respondents or equal to $9.7 \%$ have priority on perceived usefulness. Consumers see a comparison of ways to shop which is more effective and efficient in shopping. Online retail which has a better function and offers a new way of shopping still cannot beat the old shopping method in offline retail because consumers still think that the use of offline retail is still superior.

\section{Conclusion}

The conclusion of this study is the first that it turns out that respondents taken in this study stated that especially in shopping for fashion products they prefer to retail offline in shopping for fashion products. This certainly cannot be used as a guideline because this research cannot represent in terms of sample, but at least it makes a 
separate picture that the presence of online retailing does not necessarily win back offline retail consumers again. shopping places are constituted by internal stimuli one of its attitudes towards existing shopping places. The advantages offered by offline retailers are still attractive to consumers in terms of when they shop for fashion products they can touch, feel and try first so they can be more sure of choosing the product, which is not yet owned by online retailers who only present information and images that may be perceived and the expectations of each consumer differ from what is displayed and written by online retail sellers.

Certainly not necessarily consumers choose without reason in this study also discussed it turns out there are several factors of consumer attitudes that become the priority of each consumer in choosing where to shop. And it can be concluded that risk and trust are the most considered factors in consumers shopping whether it's in offline retail or online retail. And this is a concern for marketers in this case it can be concluded that it turns out that existing online retail is still considered to have a high risk for transactions and also consumers have not had high trust in online retail. And they still have high trust in offline retail because shopping there has a low risk.

\section{References}

[1] Suleman, D. (2018). Faktor penentu keputusan konsumen Indonesia memilih tempat belanja disebuah e-commerce (Theory of Planned Behavior). Jurnal Doktor Manajemen, Vol.1(No.1), pp 1-9.

[2] Kacen, J. J., Hess, J. D., \& Chiang, W.-Y. K. (2013). Bricks or Clicks? Consumer Attitudes toward Traditional Stores and Online Stores. Global Economics and Management Review, 18 (2013), pp.12-21. [3] Al-Debei, M. M., Akroush, M. N., \& Mohamed Ibrahiem Ashouri. (2015). Consumer attitudes towards online shopping: The effects of trust, perceived benefits, and perceived web quality. Internet Research, Vol. 25(Issue: 5), pp.707-733.

[4] Julianti, S. (2017). Mastering Packaging For E-commerce. Jakarta: Gramedia Pustaka Utama.

[5] Wong, D. (2017). PENGARUH ABILITY, BENEVOLENCE DAN INTEGRITY TERHADAP TRUST, SERTA IMPLIKASINYA TERHADAP PARTISIPASI PELANGGAN E-COMMERCE : STUDI KASUS PADA PELANGGAN ECOMMERCE DI UBM. Jurnal Riset Manajemen Dan Bisnis (JRMB) Fakultas Ekonomi UNIAT, Pp.155-168.

[6] Chin-Lung Hsu, Judy Chuan-Chuan Lin, H.-S. C. (2013). The effects of blogger recommendations on customers' online shopping intentions. Emerald Insight, Vol. 23(No. 1), 69-88.

[7] Liu, M., Chu, R., Wong, I., \& Zúñiga, M. (2012). Exploring the relationship among affective loyalty, perceived benefits, attitude, and intention to use co-branded products. Sia Pacific Journal of Marketing and Logistics, Vol. 4(No. 4), 561-582.

[8] Laudon, Kenneth C; Laudon, J. P. (2012). Management System:Managing the Digital Firm Twelfth Edition. New Jersey: Prentice Hall.

[9] Turban, E; Whiteside, J; King , D; Outland, J. (2017). Introduction to Electronic Commerce and Social Commerce Fourth Edition. Switzerland: Springer International Publishing.

[10] Awa, Hart Okorie; Ojiabo, Ojiabo Ukoha ; Emecheta, B. C. (2015). Integrating TAM, TPB and TOE frameworks and expanding theircharacteristic constructs for e-commerce 
adoption by SMEs. Journal of Science \& Technology Policy Management, Vol. 6(No. 1), 7694.

[11] Nitisusastro, M. (2012). Perilaku Konsumen Dalam Perspektif Kewirausahaan. Bandung: Alfabeta.

[12] Sangadji, E. M. S. (2013). Prilaku Konsumen: Pendekatan Praktis Disertai : Himpunan Jurnal Penelitian. yogyakarta: Penerbit Andi.

[13] Kotler, Phillip; Keller, K. L. (2016). Marketing Management 16 edition. New Jersey: Pearson Prentice Hall

[14] Hawkins, Del.L; Mothersbaugh, D. L. (2013). Consumer Behavior: Building Marketing Strategy. USA: McGraw-Hills.

[15] Notoatmodjo, S. (2003). Pendidikan \& Perilaku Kesehatan. Jakarta: Rineka Cipta.

[16] Suleman, D., Zuniarti, I., \& Sabil. (2019). Consumer Decisions toward Fashion Product Shopping in Indonesia: The effects of Attitude, Perception of Ease of Use, Usefulness, and Trust. Management Dynamics in the Knowledge Economy, Vol.7(no.2), pp.133-146; https://doi.org/DOI 10.25019/MDKE/7.2.01

[17] Suleman, D., Ali, H., Nusraningrum, D., \& Ali, M. M. A. (2019). Perceived Ease of Use, Trust and Risk toward Attitude and Intention in Shopping for Online Fashion Products In Indonesia. Archives of Business Research, Vol.7(No.4), pp.240-253. https://doi.org/10.14738/abr.74.6482 